Research Paper

\title{
Dual-strand tumor-suppressor microRNA-145 (miR-145-5p and miR-145-3p) coordinately targeted $M T D H$ in lung squamous cell carcinoma
}

\author{
Hiroko Mataki ${ }^{1}$, Naohiko Seki ${ }^{2}$, Keiko Mizuno ${ }^{1}$, Nijiro Nohata ${ }^{3}$, Kazuto Kamikawaji ${ }^{1}$, \\ Tomohiro Kumamoto ${ }^{1}$, Keiichi Koshizuka ${ }^{2}$, Yusuke Goto², Hiromasa Inoue ${ }^{1}$ \\ ${ }^{1}$ Department of Pulmonary Medicine, Graduate School of Medical and Dental Sciences, Kagoshima University, Kagoshima, \\ 890-8520 Japan \\ ${ }^{2}$ Department of Functional Genomics, Chiba University Graduate School of Medicine, Chuo-ku, 260-8670 Japan \\ ${ }^{3}$ Moores Cancer Center, University of California, San Diego, La Jolla, CA 92093, USA \\ Correspondence to: Naohiko Seki, email: naoseki@faculty.chiba-u.jp \\ Keywords: microRNA-145-5p, microR-145-3p, tumor-suppressor, MTDH, lung squamous cell carcinoma \\ Received: June 11,2016 Accepted: August 26, $2016 \quad$ Published: September 27, 2016
}

\section{ABSTRACT}

Patients with lung adenocarcinoma may benefit from recently developed molecular targeted therapies. However, analogous advanced treatments are not available for patients with lung squamous cell carcinoma (lung SCC). The survival rate of patients with the advanced stage of lung SCC remains poor. Exploration of novel lung SCC oncogenic pathways might lead to new treatment protocols for the disease. Based on this concept, we have identified microRNA- (miRNA) mediated oncogenic pathways in lung SCC. It is well known that $m i R-145-5 p$ (the guide strand) functions as a tumor suppressor in several types of cancer. However, the impact of miR-145$3 p$ (the passenger strand) on cancer cells is still ambiguous. Expression levels of $m i R-145-5 p$ and $m i R-145-3 p$ were markedly reduced in cancer tissues, and ectopic expression of these miRNAs inhibited cancer cell aggressiveness, suggesting that both miR-145-3p as well as miR-145-5p acted as antitumor miRNAs. We identified seven putative target genes (MTDH, EPN3, TPD52, CYP27B1, LMAN1, STAT1 and TXNDC12) that were coordinately regulated by $m i R-145-5 p$ and $m i R-145-3 p$ in lung SCC. Among the seven genes, we found that metadherin (MTDH) was a direct target of these miRNAs. Kaplan-Meier survival curves showed that high expression of MTDH predicted reduced survival of lung SCC patients. We investigated pathways downstream from MTDH by using genome-wide gene expression analysis. Our data showed that several anti-apoptosis and pro-proliferation genes were involved in pathways downstream from MTDH in lung SCC. Taken together, both strands of miR-145, miR-145-5p and miR-145-3p are functional and play pivotal roles as antitumor miRNAs in lung SCC.

\section{INTRODUCTION}

Lung cancer is the most frequent cause of cancerrelated death worldwide [1]. Non-small cell lung cancer (NSCLC) is the most common type of lung cancer and is divided into three subtypes according to pathogenesis: adenocarcinoma, squamous cell carcinoma and large cell carcinoma [2]. Recent developments in molecular targeted therapies have improved the overall survival of patients with lung adenocarcinoma [3]. In contrast, there is a lack of effective therapeutic options to treat patients with lung squamous cell carcinoma (lung SCC) [3].
In that regard, cancer cell metastasis is known to be an important prognostic indicator of lung cancer. Thus, we hypothesized that current genomic approaches might be used to elucidate the molecular mechanisms underlying lung SCC metastasis and suggest improved treatments for this disease.

MicroRNA (miRNA) is a class of small non-coding RNAs. They are involved in the repression or degradation of target RNA transcripts in a sequence-dependent manner [4-6]. Aberrantly expressed miRNAs can dysregulate cellular RNA networks critical for normal cell function. The resultant failure of RNA networks promotes malignant 
transformation of cancer cells [7-9]. Identification of aberrantly expressed miRNAs is the first step to defining the oncogenic RNA networks in cancer cells. With that in mind, we used clinical specimens to construct miRNA expression signatures of various types of human cancer [10-14]. Using these signatures, we identified antitumor miRNAs and miRNA-regulated oncogenic genes [10-14]. Our recent studies of lung SCC revealed that $m i R-1 / m i R-133 a$ clustered miRNAs, $m i R-206$ and the miR-29-family inhibited cancer cell migration and invasion through targeting of several oncogenic genes, such as coronin-1C (CORO1C), $c-M E T$ and lysyl oxidase like 2 (LOXL2) [15-17].

Using miRNA expression signatures obtained by deep sequencing, we found that expression levels of $m i R$ $145-5 p$ (the guide strand of pre-miR-145) and $m i R-145-3 p$ (the passenger strand of pre-miR-145) were significantly reduced in cancer tissues, suggesting that these miRNAs functioned as tumor-suppressors [18]. It is believed that the guide strand RNA from duplex miRNA is retained to direct recruitment of the RNA-induced silencing complex (RISC) to target messenger RNAs. In contrast, the passenger strand RNA is degraded in the course of miRNA biogenesis [19]. Our recent study overturned this convention. We found that both the miR-144-5p strand and the miR-144-3p strand derived from pre-miR-144 acted as tumor suppressors in bladder cancer (BC) cells [20]. Moreover, we showed that $m i R-145-3 p$ acted as a tumor-suppressor in $\mathrm{BC}$ cells, indicating that the passenger strand of miRNA has pivotal roles in human cancer pathogenesis [18].

Downregulation of miR-145-5p was reported in several cancers, establishing its function as a tumorsuppressor [21-26]. However, the role of $m i R-145-3 p$ on lung cells is still ambiguous. The aims of the present study were to investigate the anti-tumor effects of $m i R-145-3 p$ as well as $m i R-145-5 p$ in lung cells. We also sought to identify oncogenic RNA networks in lung SCC and the genes regulated by these miRNAs. Our present data showed that $m i R-145-3 p$ functions as a tumor-suppressor as well as $m i R$ $145-5 p$ in lung SCC cells. Moreover, gene expression data and in silico database analysis showed that the metadherin gene $(M T D H)$, also known as astrocyte elevated gene-1 $(A E G-1)$ was a direct target of both miR-145-5p and miR$145-3 p$ regulation. Kaplan-Meier survival curves showed that high expression of $M T D H$ predicted poorer survival of lung SCC patients. The discovery of new tumor-suppressor functions of both miRNAs strands of miR-145 (miR-145-5p and $m i R-145-3 p$ ) provides new insight into the molecular mechanisms of lung SCC pathogenesis.

\section{RESULTS}

\section{Expression levels of $m i R-145-5 p$ and $m i R-145-3 p$ in lung SCC clinical specimens and cell lines}

We evaluated the expression levels of dual strand miRNAs of pre-miR-145 (miR-145-5p and miR-145-3p) in lung SCC tissues. The expression levels of $m i R-145-5 p$ and $m i R-145-3 p$ were significantly reduced in lung SCC tissues compared to noncancerous tissues $(P=0.0012$ and $P<0.0001$, respectively, Figure 1A). Spearman's rank test showed positive correlations between the expression of $m i R-145-5 p$ and $m i R-145-3 p(\mathrm{R}=0.616$ and $P<0.0001$; Figure 1B).

The patients' backgrounds and clinicopathological characteristics are summarized in Table 1A. Normal lung tissues are summarized in Table 1B. There were no significant relationships between any of the clinicopathological parameters (i.e., tumor grade, stage, metastasis, or survival rate) and the expression levels of $m i R-145-5 p$ and $m i R-145-3 p$ (data not shown).

\section{Effects of ectopic expression of $m i R-145-5 p$ or $m i R-145-3 p$ on cell proliferation, migration and invasion in SK-MES-1 and EBC-1 cells}

To investigate the functional roles of $m i R-145-5 p$ and $m i R-145-3 p$, we performed gain-of-function studies using mature miRNA transfections of SK-MES-1 and EBC-1 cells. The expression levels of $m i R-145-5 p$ and $m i R-145-3 p$ were significantly lower in two cell lines (Figure 1A).

XTT assays revealed significant inhibition of cell proliferation in SK-MES-1 cells transfected with $m i R$ $145-5 p$ or $m i R-145-3 p$ in comparison with mock or control transfectants $(P<0.05$, Figure 1C). EBC-1 cells transfected with $m i R-145-3 p$, there was no significant inhibition of cell proliferation in comparison with control transfectants (Figure 1C).

Wound healing assays showed significant inhibition of cell migration activity after transfection with $m i R-145$ $5 p$ or $m i R-145-3 p(P<0.001$, Figure 1D).

Similarly, Matrigel invasion assays revealed that transfection with $m i R-145-5 p$ of $m i R-145-3 p$ reduced cell invasion activities $(P<0.001$, Figure 1E).

To investigate the synergistic effects of $m i R-145$ $5 p$ and $m i R-145-3 p$, we performed functional assays (cell proliferation, migration and invasion assays) with co-transfection of mature miR-145-5p and miR-145-3p in EBC-1 cells. In this assays, we did not detected the synergistic effects by using these miRNAs transfection (Supplementary Figure S1)

\section{Identification of target genes coordinately regulated by $m i R-145-5 p$ and $m i R-145-3 p$ in lung SCC cells}

To identify target genes coordinately regulated by $m i R-145-5 p$ and $m i R-145-3 p$, we performed a combination of in silico analyses, oligomicroarray expression analyses and Gene Omnibus database (GEO) analyses.

The TargetScan database showed that 4,405 and 3,164 genes have putative target sites for $m i R-145-5 p$ and $m i R$ - 
145-3p in their 3'UTRs, respectively. Next, we performed genome-wide gene expression analysis using EBC-1 cells (GEO accession number GSE77790). Genes downregulated $\left(\log _{2}\right.$ ratio $\left.<-1.0\right)$ by transfection with $m i R-145-5 p$ or $m i R-$ $145-3 p$ were selected as putative target genes. A total of 314 and 155 genes were downregulated in $m i R-145-5 p$ and $m i R$ $145-3 p$ transfectants, respectively. We found that there were 13 common genes targeted by both miRNAs. Finally, to evaluate upregulated genes in clinical NSCLC specimens, we examined gene expression profiles in the GEO database (accession numbers GSE19188).

A total of 7 putative candidate genes for both $m i R$ 145-5p and $m i R-145-3 p$ regulation were identified (Table 2 ). A flow chart describing the strategy for analysis of $m i R$ $145-5 p$ and $m i R-145-3 p$ target genes is shown in Figure 2A. We examined real-time RT-qPCR analyses of EBC-1 cells to investigate whether restoration of $m i R-145-5 p$ or $m i R$ $145-3 p$ expression altered the expression of 7 genes mRNA. The mRNA expression levels of 7 candidate genes were shown in Figure 2B. Among these genes, MTDH, EPN3, LMAN1, STAT1, and TXNDC12 were significantly repressed
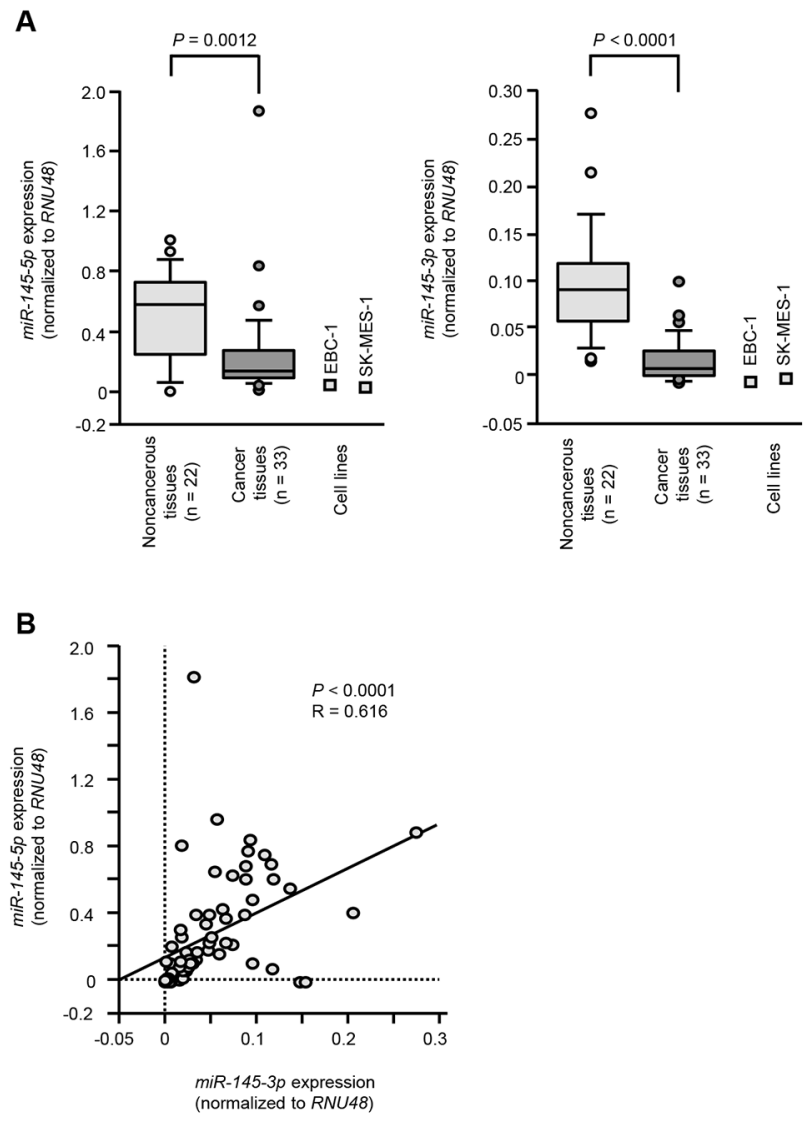

Figure 1: The expression levels of $m i R-145-5 p$ and $m i R-145-3 p$ in lung SCC cells and their ectopic effects in cancer cells. A. Expression levels of $m i R-145-5 p$ and $m i R-145-3 p$ in lung SCC clinical specimens and cell lines (SK-MES-1 and EBC-1) were determined by qRT-PCR. Data were normalized to RNU48 expression. B. Correlation of the expression levels of $m i R-145-5 p$ and $m i R-$ 145-3p. C. Cell growth was determined by XTT assays $72 \mathrm{~h}$ after transfection with $10 \mathrm{nM} m i R-145-5 p$ or $m i R-145-3 p . * P<0.05$. D. Cell migration activity was determined by wound healing assays. $* P<0.001$. E. Cell invasion activity was determined using Matrigel invasion assays. ${ }^{*} P<0.001$ in $m i R-145-5 p$ transfectants as compared with mock- or miR-control-transfected cells. All candidate target genes were significantly repressed in $m i R-145-3 p$ transfectants as compared with mock- or miR-control-transfected cells.

We did not detected the synergistic effects (cotransfection of $m i R-145-5 p$ and $m i R-145-3 p$ ) for expression status of MTDH in SK-MES-1 and EBC-1 cells (Supplementary Figure S2).

\section{$M T D H$ was direct target by $m i R-145-5 p$ and miR-145-3p in lung SCC cells}

We performed real-time RT-qPCR and Western blotting analyses of SK-MES-1 and EBC-1 cells to investigate whether restoration of $m i R-145-5 p$ or $m i R$ 145-3p expression altered the expression of $M T D H$ mRNA and MTDH protein. The mRNA and protein expression levels of $M T D H / M T D H$ were significantly repressed in $m i R-m i R-145-5 p$ or $m i R-145-3 p$ transfectants as compared with mock- or miR-control-transfected cells (Figure 3A and 3B).
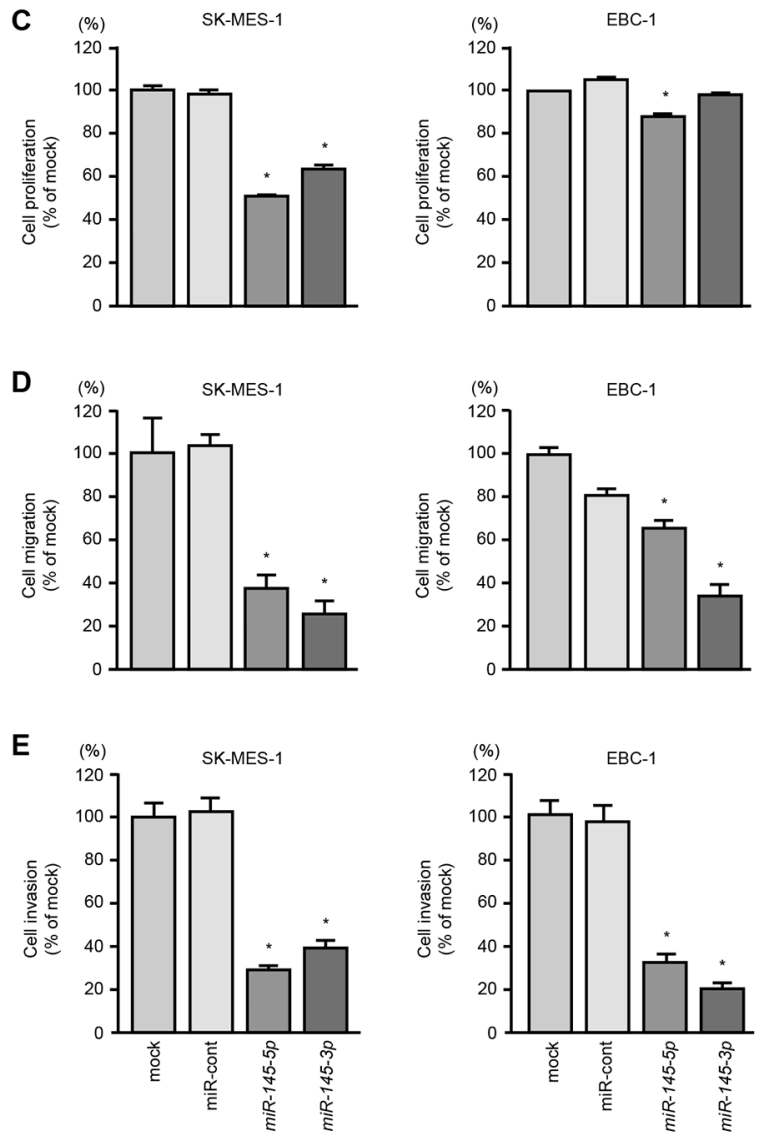
Table 1A: Characteristic of patients

\begin{tabular}{|c|c|c|c|}
\hline Lung cancer & & $\mathrm{SCC}$ & $(\%)$ \\
\hline Total number & & 33 & \\
\hline Median age (range) & & $70(50-88)$ & \\
\hline \multicolumn{4}{|l|}{ Gender } \\
\hline & Male & 31 & $(93.9)$ \\
\hline & Female & 2 & $(6.1)$ \\
\hline \multicolumn{4}{|c|}{ Pathological tumor stage } \\
\hline & IA & 5 & $(15.2)$ \\
\hline & IB & 8 & $(24.2)$ \\
\hline & IIA & 4 & $(12.1)$ \\
\hline & IIB & 6 & $(18.2)$ \\
\hline & IIIA & 8 & $(24.2)$ \\
\hline & IIIB & 1 & $(3.0)$ \\
\hline & unknown & 1 & $(3.0)$ \\
\hline \multicolumn{4}{|l|}{ Differentiation } \\
\hline & well & 8 & $(24.2)$ \\
\hline & moderately & 20 & $(60.6)$ \\
\hline & poorly & 3 & $(9.1)$ \\
\hline & unknown & 2 & $(6.1)$ \\
\hline \multicolumn{4}{|l|}{ Pleural invasion } \\
\hline & $(+)$ & 15 & $(45.5)$ \\
\hline & $(-)$ & 18 & $(54.5)$ \\
\hline \multicolumn{4}{|l|}{ Venous invasion } \\
\hline & $(+)$ & 16 & $(48.5)$ \\
\hline & $(-)$ & 17 & $(51.5)$ \\
\hline \multicolumn{4}{|l|}{ Lymphatic invasion } \\
\hline & $(+)$ & 16 & $(48.5)$ \\
\hline & $(-)$ & 17 & $(51.5)$ \\
\hline
\end{tabular}

Table 1B: Characteristic of Patients

\begin{tabular}{lcc}
\hline Normal lung & n \\
\hline Total number & & 22 \\
Median age (range) & & $71(50-88)$ \\
Gender & & 22 \\
& Male & 0 \\
\hline
\end{tabular}

We next performed luciferase reporter assays using EBC-1 cells to determine whether MTDH mRNA had target sites for miR-145-5p and miR-145-
$3 p$. The TargetScan database identified two putative target sites in the 3'-UTR of MTDH for miR-145-5p (position 3151-3157 and position 3503-3510) and 
Table 2: Downregulated genes in $m i R-145-5 p / 3 p$ transfectant

\begin{tabular}{|c|c|c|c|c|c|c|c|c|}
\hline \multirow{2}{*}{$\begin{array}{l}\text { Entrez } \\
\text { Gene } \\
\text { ID }\end{array}$} & \multirow{2}{*}{$\begin{array}{c}\text { common } \\
\text { target }\end{array}$} & \multirow[t]{2}{*}{ Gene name } & \multicolumn{2}{|c|}{$m i R-145-5 p$} & \multirow{2}{*}{$\begin{array}{c}\text { miR-145-3p } \\
\begin{array}{c}\text { poorly } \\
\text { conserved }\end{array}\end{array}$} & \multirow{2}{*}{$\begin{array}{l}\text { miR-145-5p } \\
\text { transfection } \\
\quad\left(\log _{2}\right)\end{array}$} & \multirow{2}{*}{$\begin{array}{c}\text { miR-145-3p } \\
\text { transfection } \\
\quad\left(\log _{2}\right)\end{array}$} & \multirow{2}{*}{$\begin{array}{c}\text { GSE19188 } \\
\text { (fold-change) }\end{array}$} \\
\hline & & & conserved & $\begin{array}{c}\text { poorly } \\
\text { conserved }\end{array}$ & & & & \\
\hline 92140 & $M T D H$ & metadherin & 1 & 1 & 1 & -1.03 & -1.34 & 1.29 \\
\hline 55040 & EPN3 & epsin 3 & 0 & 1 & 1 & -1.00 & -1.28 & 6.01 \\
\hline 7163 & TPD52 & $\begin{array}{c}\text { tumor protein } \\
\text { D52 }\end{array}$ & 0 & 2 & 1 & -1.18 & -1.26 & 2.66 \\
\hline 1594 & CYP27B1 & $\begin{array}{c}\text { cytochrome } \\
\text { P450, } \\
\text { family } 27, \\
\text { subfamily } B, \\
\text { polypeptide } 1\end{array}$ & 0 & 1 & 2 & -1.74 & -1.40 & 2.12 \\
\hline 79748 & LMAN1 & $\begin{array}{c}\text { lectin, } \\
\text { mannose- } \\
\text { binding, } 1\end{array}$ & 0 & 1 & 1 & -1.08 & -1.14 & 1.78 \\
\hline 6772 & STAT1 & $\begin{array}{c}\text { signal } \\
\text { transducer } \\
\text { and } \\
\text { activator of } \\
\text { transcription } \\
1,91 \mathrm{kDa}\end{array}$ & 0 & 1 & 1 & -1.30 & -1.01 & 1.61 \\
\hline 51060 & $T X N D C 12$ & $\begin{array}{l}\text { thioredoxin } \\
\text { domain } \\
\text { containing } 12 \\
\text { (endoplasmic } \\
\text { reticulum) }\end{array}$ & 0 & 1 & 1 & -2.13 & -2.72 & 1.20 \\
\hline
\end{tabular}

A

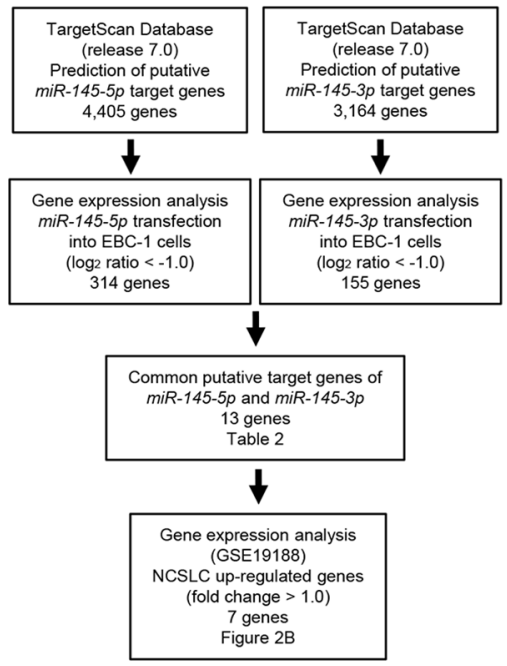

B

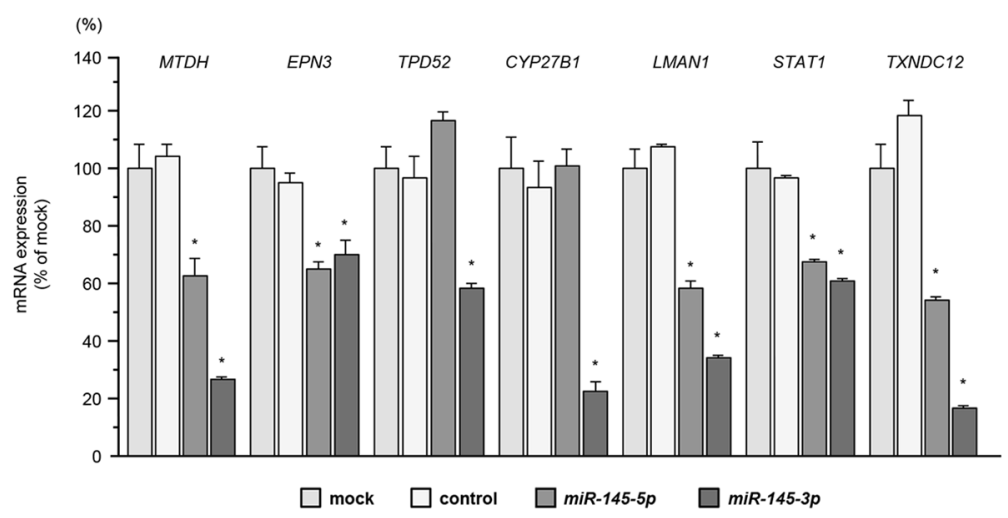

Figure 2: Identification of genes coordinately regulated by $m i R-145-5 p$ and $m i R-145-3 p$. A. Flow chart illustrates the strategy for analysis of $m i R-145-5 p$ and $m i R-145-3 p$ target genes in lung SCC cells. B. Identification of target genes of $m i R-145-5 p$ or $m i R-145-3 p$. Expression levels of 7 mRNAs (MTDH, EPN3, TPD52, CYP27B1, LMAN1, STAT1 and TXNDC12) were evaluated by qRT-PCR in EBC-1 cells $72 \mathrm{~h}$ after transfection with $m i R-145-5 p$ or $m i R-145-3 p$. GUSB was used as an internal control. ${ }^{*} P<0.0001$. 
one site for $m i R-145-3 p$ (position 147-153) (Figure $3 C)$. We used vectors encoding a partial wild-type sequence of the 3'-UTR of MTDH mRNA, including the predicted $m i R-145-5 p$ and $m i R-145-3 p$ target site, or a vector lacking the $m i R-145-5 p$ and $m i R-145-3 p$ target sites. We found that the luminescence intensity was significantly reduced by co-transfection with $m i R$ $145-5 p$ or $m i R-145-3 p$ and the vector carrying the wild-type 3'-UTR of $M T D H$. On the other hand, the luminescence intensity was not decreased when the seed sequences of the target sites were deleted from the vectors $(P=0.0054, P<0.001$, and $P<0.001$, respectively; Figures $3 \mathrm{D}-3 \mathrm{~F}$ ).

\section{Effects of silencing $M T D H$ on cell aggressiveness in lung $\mathrm{SCC}$ cells}

We investigated the oncogenic function of $M T D H$ in lung SCC cells by using si-MTDH transfectants. We evaluated the knockdown efficiency of si-MTDH transfection in lung SCC cells. Present data indicated that si-MTDH effectively downregulated $M T D H / M T D H$ expression in lung SCC cells (Figure 4A and 4B).

Cell proliferation was inhibited by si-MTDH transfectants in comparison with mock or si-control transfectants in EBC-1 cells $(P<0.05$, Figure 4C). However in SK-MES-1 cells transfected with si-MTDH-1,

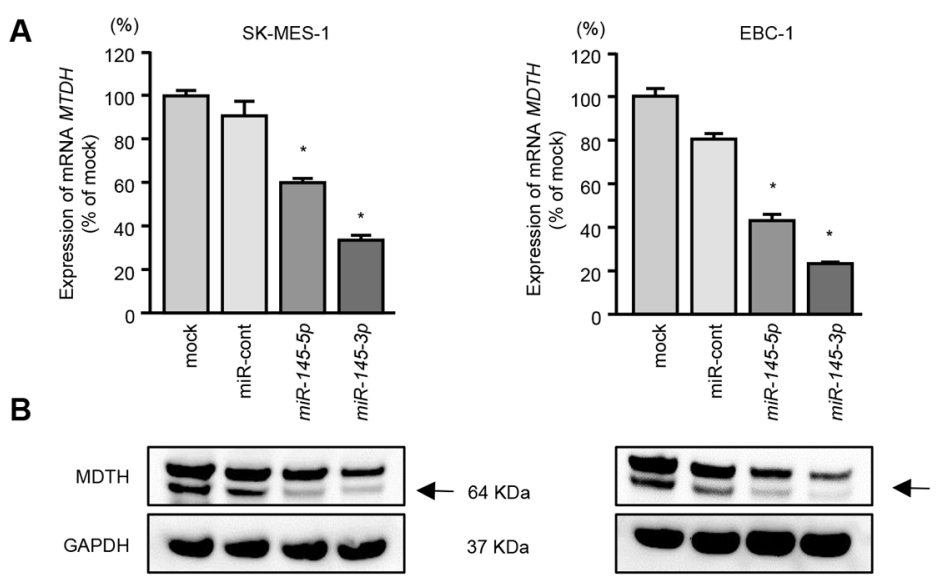

C
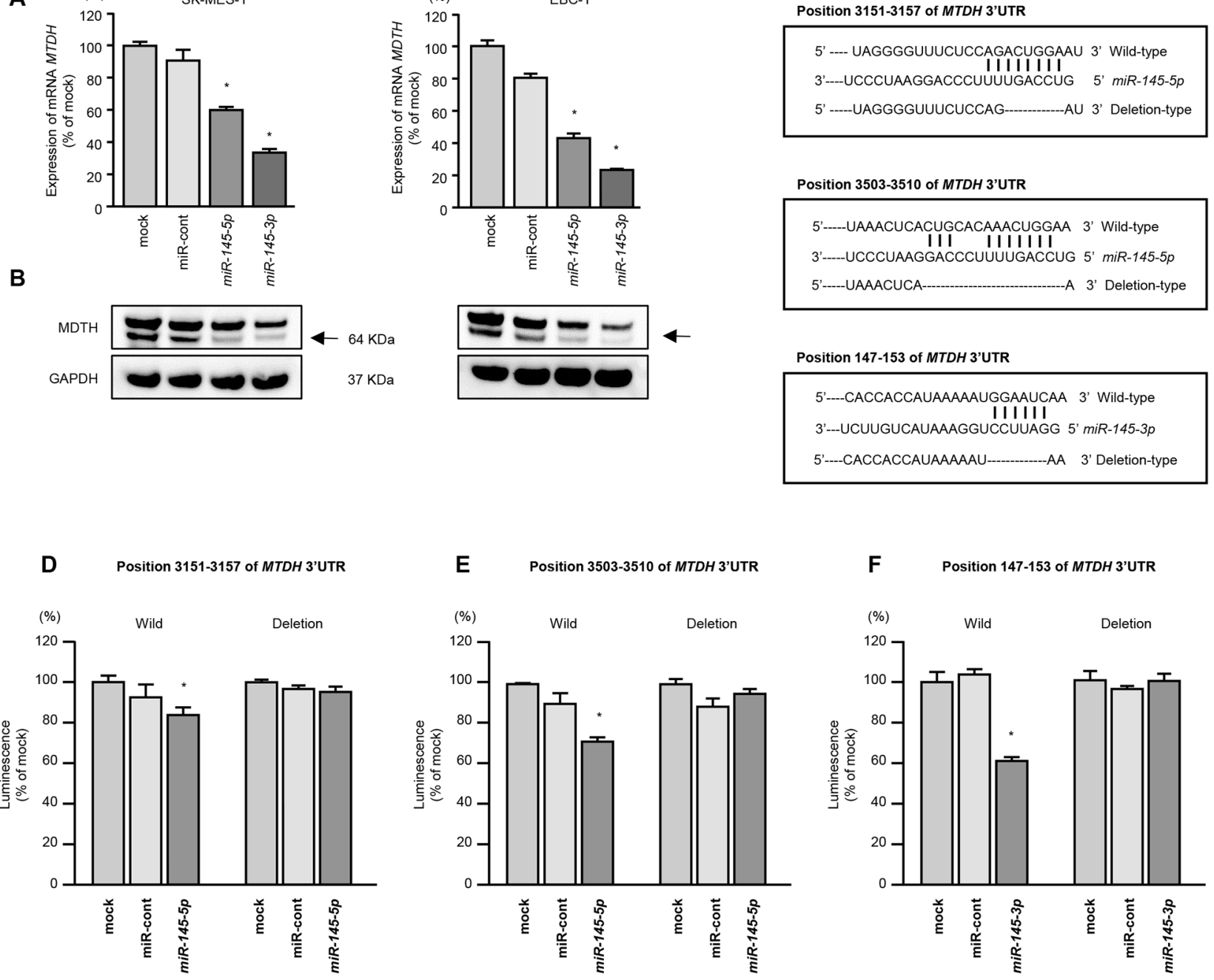

Figure 3: Direct regulation of $M T D H$ by $m i R-145-5 p$ or $\boldsymbol{m i R}-145-3 p$ in lung SCC cells. A. $M T D H$ mRNA expression was evaluated by qRT-PCR in SK-MES-1 and EBC-1 cells $72 \mathrm{~h}$ after transfection with $m i R-145-5 p$ or $m i R-145-3 p$. GUSB was used as an internal control. $* P<0.0001$. B. MTDH protein expression was evaluated by Western blot analyses in SK-MES-1 and EBC-1 $72 \mathrm{~h}$ after transfection with $m i R-145-5 p$ or $m i R-145-3 p$. GAPDH was used as a loading control. C. $m i R-145-5 p$ or $m i R-145-3 p$ binding sites in the 3'-UTR of MTDH mRNA. (D-F) Dual luciferase reporter assays using vectors encoding putative miR-145-5p (positions 3,151-3,157 or 3,503-3,510) or miR-145-3p (147-153) target sites of the MTDH 3'-UTR for both wild-type and deleted regions. Normalized data were calculated as ratios of Renilla/firefly luciferase activities. ${ }^{*} P=0.0054, P<0.001$, and $P<0.001$ for D-F., respectively. 
proliferation was not inhibited in comparison with mock or si-control transfectants (Figure 4C).

Wound healing and Matrigel invasion assays showed significant inhibition of cell migration and invasion by si$M T D H$ transfectants $(P<0.001$, Figures $4 \mathrm{D}$ and $4 \mathrm{E})$.

\section{Expression of $M T D H$ in clinical lung SCC specimens}

The mRNA expression levels of $M T D H$ were significantly upregulated in lung SCC clinical samples (Figure 5A). As for $M T D H$ copy number variation (CNV), our study showed that $60 \%$ of lung SCC patients had a genetic alteration (Figure 5B and 5C). The mRNA expression levels of $M T D H$ significantly increased in accordance with the increase of $M T D H$ gene copy number (Figure 5D). We assessed the Kaplan-Meier univariate survival of patients groups, comparing those with an
$M T D H$ alteration (CNV amplification or gain, or mRNA Z-score $>1.5$ ) and those without an $M T D H$ alteration (diploid or heterozygous loss, and mRNA Z-score equal or less than 1.5). The $M T D H$ altered group had a significantly poorer overall survival $[P=0.0370]$ (Figure 5E).

\section{Identification of $\mathrm{MTDH}$-mediated downstream pathways in lung SCC cells}

To identify the downstream genes regulated by $M T D H$, genome-wide gene expression analyses and in silico analyses were performed in lung SCC cells transfected with si-MTDH. Our present expression data using EBC-1 cells was deposited in GEO database (GEO accession number: GSE82108).

A total of 1,841 genes were reduced in si-MTDH transfected cells. Downregulated genes (top 40 genes) were listed in Supplementary Tables S1A and S1B.
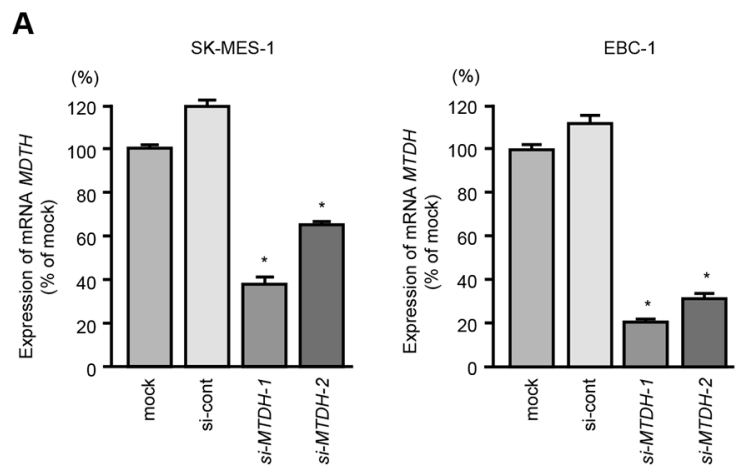

B

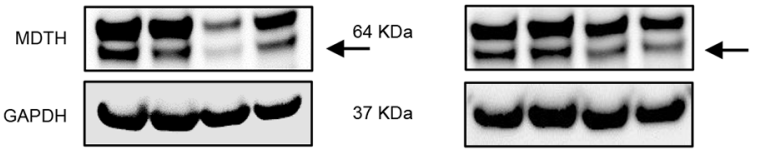

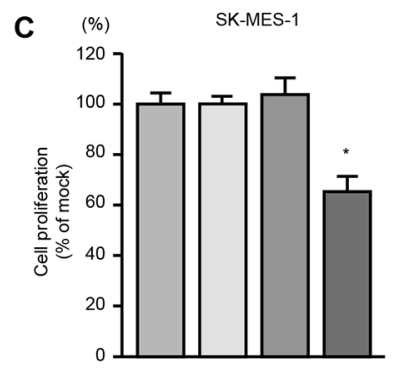
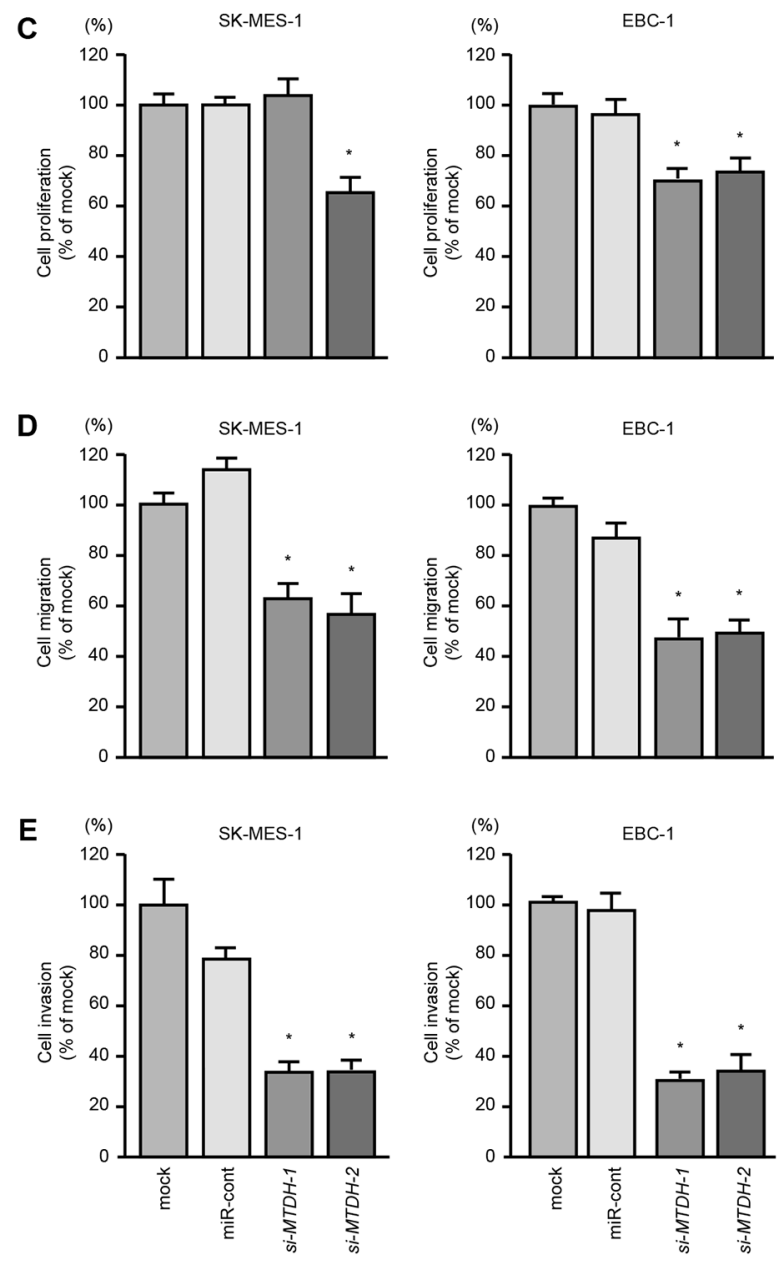

Figure 4: Effects of $\boldsymbol{M T D H}$ silencing in lung SCC cell lines. A. $M T D H$ mRNA expression was evaluated by qRT-PCR in SKMES-1 and EBC-1 $72 \mathrm{~h}$ after transfection with $s i-M T D H-1$ or $s i-M T D H-2$. GUSB was used as an internal control. B. MTDH protein expression was evaluated by Western blot analysis in SK-MES-1 and EBC-1 $72 \mathrm{~h}$ after transfection with $m i R-145-5 p$ or $m i R-145-3 p$. GAPDH was used as a loading control. C. Cell proliferation was determined with the XTT assays $72 \mathrm{~h}$ after transfection with $10 \mathrm{nM}$ si-MTDH-1 or si-MTDH-2. $* P<0.05$. D. Cell migration activity was determined by wound healing assays. $* P<0.001$. E. Cell invasion activity was determined using Matrigel invasion assays. ${ }^{*} P<0.001$. 
Furthermore, to investigate the functional roles of $M T D H-$ mediated genes, we categorized these downregulated genes by KEGG pathways. Genes involved in these pathways are listed in Supplementary Table S2. Among these pathways, we focused on "Focal adhesion", "Pathways in cancer" and "Endocytosis" pathways because $M T D H$ contributed to cancer cell migration and invasion (Table 3).

\section{DISCUSSION}

In miRNA biogenesis, processing of the pre-miRNA through Dicer1 generates a miRNA duplex (a passenger strand and a guide strand). The guide strand RNA from the duplex is retained and recruited to the RNA induced silencing complex (RISC) to target messenger RNAs, whereas the passenger strand has no regulatory activity and is degraded $[27,28]$. Our recent studies showed that passenger strands of some miRNAs (miR-144-3p and $m i R-145-3 p$ ) have antitumor functions and directly target several oncogenic genes in BC cells $[18,20]$. In this study, we demonstrated that $m i R-145-3 p$ (passenger strand) had antitumor functions as did $m i R-145-5 p$ (guide strand) in lung SCC cells. A large number of studies showed the antitumor function of $m i R-145-5 p$ in several cancers, including lung cancer [21-26]. Based on previous studies and our data, both strands of pre-miR-145 (miR-145-5p and $m i R-145-3 p$ ) act as antitumor miRNAs in cancer cells.

We hypothesized that miR-145-5p and miR-145-3p coordinately regulated target genes that significantly contributed to lung SCC pathogenesis. In this study, we applied in silico and gene expression analyses described in our previous studies [15-17, 18, 20]. Using that strategy, we previously found that ubiquitin-like with PHD and ring finger domains 1 (UHRF1) was directly regulated by both $m i R-145-5 p$ and $m i R-145-3 p$ in BC [18]. Moreover, we showed that UHRF1 was overexpressed in BC clinical specimens and that the high $U H R F 1$ expression group had a significantly poorer cause-specific survival rate in comparison with the low expression group [18].

Here, we identified 7 putative candidate genes (MTDH, EPN3, TPD52, CYP27B1, LMAN1, STAT1 and $T X N D C 12)$ that were regulated by both $m i R-145-5 p$ and $m i R-145-3 p$ in lung SCC cells. Several studies showed that TPD52 was overexpressed in several cancers, and function as an oncogenes [29, 30]. Recent study indicated

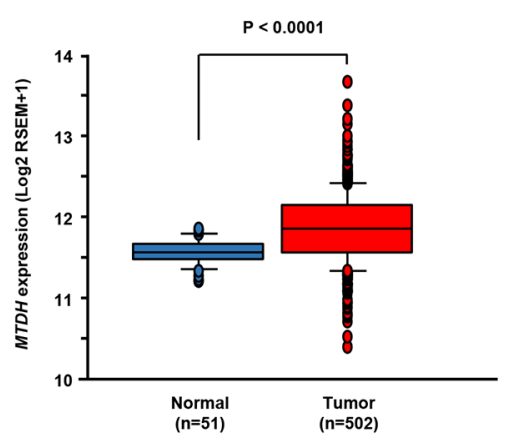

D

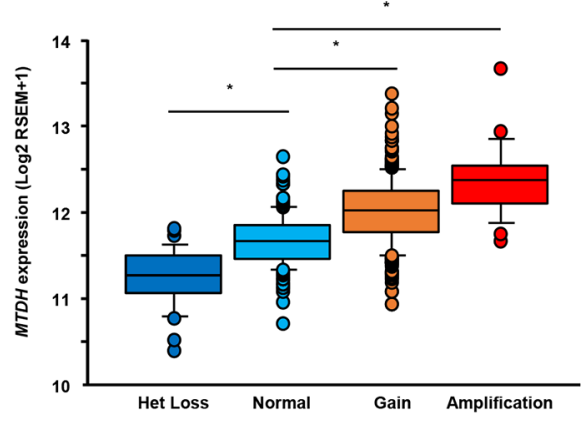

B

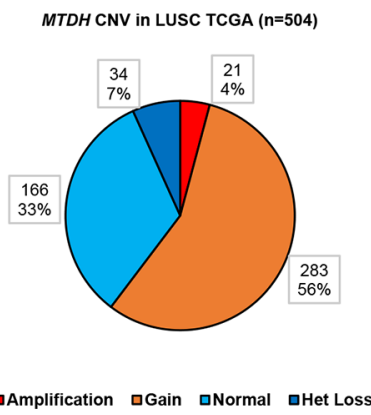

C

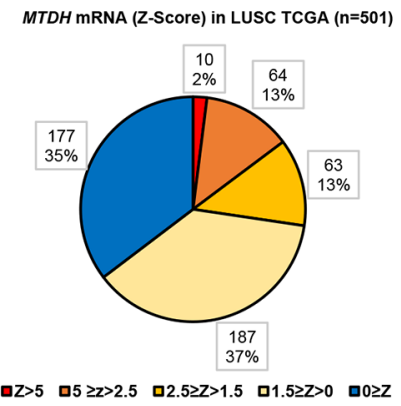

E

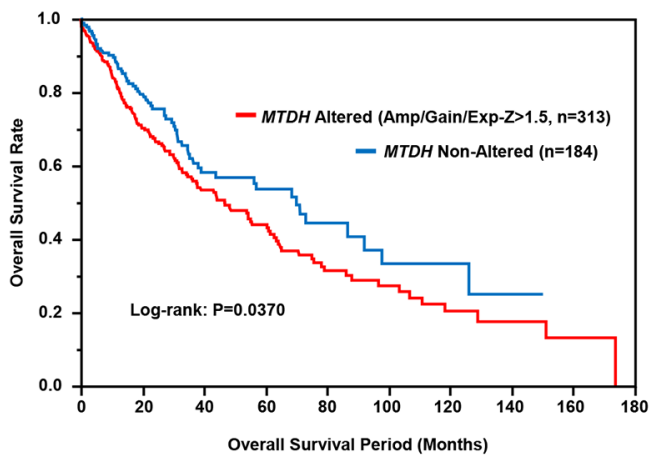

Figure 5: Clinical significance of $M T D H$ expression in lung SCC based on TCGA database. A. Comparison of $M T D H$ mRNA expression levels between normal and tumor samples. B, C. The distribution of MTDH genomic copy number variation $(\mathrm{n}=504)$ and mRNA Z-score $(\mathrm{n}=501)$ in LUSCC TCGA. D. Box-and-whisker plots of $M T D H$ mRNA expression with respect to genomic copy number $* P<0.0001$. E. Clinical outcome for patients with altered $M T D H(\mathrm{CNV}$, amplification or gain, or mRNA Z-score $>1.5)$ or nonaltered $M T D H(\mathrm{CNV}$, diploid or het loss, and mRNA Z-score $\leq 1.5)$ are displayed as Kaplan-Meier plots with log-rank tests. 
Table 3A: Downregulated genes by si-MTDH in "Focal adhesion pathway"

\begin{tabular}{|c|c|c|c|c|c|}
\hline \multirow[t]{2}{*}{$\begin{array}{l}\text { Entrez } \\
\text { gene ID }\end{array}$} & \multirow[t]{2}{*}{ Gene symbol } & \multirow[t]{2}{*}{ Description } & \multicolumn{2}{|c|}{$\begin{array}{l}\text { si-MTDH transfectant } \\
\text { (fold-change) }\end{array}$} & \multirow[t]{2}{*}{$\begin{array}{c}\text { GSE19188 } \\
\text { (fold-change) }\end{array}$} \\
\hline & & & SiRNA1 & SiRNA2 & \\
\hline 1290 & COL5A2 & collagen, type $\mathrm{V}$, alpha 2 & 0.02 & -0.07 & 3.55 \\
\hline 3688 & $I T G B 1$ & integrin, beta 1 & -2.28 & -0.05 & 2.64 \\
\hline 2317 & $F L N B$ & filamin B, beta & -2.20 & -2.01 & 2.43 \\
\hline 7422 & $V E G F A$ & vascular endothelial growth factor A & -2.06 & 0.36 & 1.99 \\
\hline 3915 & $L A M C 1$ & laminin, gamma 1 (formerly LAMB2) & -3.22 & 0.18 & 1.61 \\
\hline 1956 & $E G F R$ & epidermal growth factor receptor & -2.30 & -0.88 & 1.50 \\
\hline 3371 & $T N C$ & tenascin $\mathrm{C}$ & -4.17 & -0.37 & 1.46 \\
\hline 5501 & PPP1CC & $\begin{array}{c}\text { protein phosphatase } 1 \text {, catalytic subunit, } \\
\text { gamma isozyme }\end{array}$ & -0.60 & -2.04 & 1.42 \\
\hline 5500 & $P P P 1 C B$ & $\begin{array}{c}\text { protein phosphatase } 1 \text {, catalytic subunit, } \\
\text { beta isozyme }\end{array}$ & -4.54 & -2.17 & 1.37 \\
\hline 10000 & AKT3 & $\begin{array}{l}\text { v-akt murine thymoma viral oncogene } \\
\text { homolog } 3\end{array}$ & -2.73 & -2.19 & 1.37 \\
\hline 394 & ARHGAP5 & Rho GTPase activating protein 5 & -2.63 & 0.00 & 1.36 \\
\hline 208 & $A K T 2$ & $\begin{array}{l}\text { v-akt murine thymoma viral oncogene } \\
\text { homolog } 2\end{array}$ & 0.22 & -2.70 & 1.34 \\
\hline 5578 & $P R K C A$ & protein kinase $C$, alpha & -0.26 & -3.17 & 1.30 \\
\hline 3914 & $L A M B 3$ & laminin, beta 3 & -2.31 & -0.20 & 1.04 \\
\hline
\end{tabular}

Table 3B: Downregulated genes by si-MTDH in "Pathways in cancer"

\begin{tabular}{|c|c|c|c|c|c|}
\hline \multirow[t]{2}{*}{ Entrez gene ID } & \multirow[t]{2}{*}{ Gene symbol } & \multirow[t]{2}{*}{ Description } & \multicolumn{2}{|c|}{$\begin{array}{l}\text { si-MTDH transfectant } \\
\text { (fold-change) }\end{array}$} & \multirow[t]{2}{*}{$\begin{array}{c}\text { GSE19188 } \\
\text { (fold-change) }\end{array}$} \\
\hline & & & siRNA1 & SiRNA2 & \\
\hline 6513 & $S L C 2 A 1$ & $\begin{array}{l}\text { solute carrier family } \\
2 \text { (facilitated glucose } \\
\text { transporter), member } 1\end{array}$ & -2.02 & -0.30 & 6.34 \\
\hline 112399 & EGLN3 & $\begin{array}{l}\text { egl-9 family hypoxia- } \\
\text { inducible factor } 3\end{array}$ & -2.67 & -0.48 & 5.97 \\
\hline 5888 & RAD51 & RAD51 recombinase & -1.08 & 1.16 & 4.24 \\
\hline 4318 & $M M P 9$ & $\begin{array}{c}\text { matrix metallopeptidase } \\
9 \text { (gelatinase } \mathrm{B}, 92 \mathrm{kDa} \\
\text { gelatinase, } 92 \mathrm{kDa} \text { type IV } \\
\text { collagenase) }\end{array}$ & -0.02 & -2.41 & 4.12 \\
\hline 1163 & $C K S 1 B$ & $\begin{array}{l}\mathrm{CDC} 28 \text { protein kinase } \\
\text { regulatory subunit } 1 \mathrm{~B}\end{array}$ & -2.27 & 0.87 & 3.42 \\
\hline 5337 & PLD1 & $\begin{array}{l}\text { phospholipase D1, } \\
\text { phosphatidylcholine-specific }\end{array}$ & -0.82 & -2.39 & 2.83 \\
\hline 3688 & $I T G B 1$ & integrin, beta 1 & -2.28 & -0.05 & 2.64 \\
\hline 5578 & $P R K C A$ & protein kinase $\mathrm{C}$, alpha & -0.26 & -3.17 & 2.08 \\
\hline & & & & & (Continued \\
\hline
\end{tabular}




\begin{tabular}{|c|c|c|c|c|c|}
\hline \multirow[t]{2}{*}{ Entrez gene ID } & \multirow[t]{2}{*}{ Gene symbol } & \multirow[t]{2}{*}{ Description } & \multicolumn{2}{|c|}{$\begin{array}{l}\text { si-MTDH transfectant } \\
\text { (fold-change) }\end{array}$} & \multirow[t]{2}{*}{$\begin{array}{c}\text { GSE19188 } \\
\text { (fold-change) }\end{array}$} \\
\hline & & & siRNA1 & siRNA2 & \\
\hline 7184 & HSP90B1 & $\begin{array}{l}\text { heat shock protein } 90 \mathrm{kDa} \\
\text { beta (Grp94), member } 1\end{array}$ & -2.88 & 0.03 & 2.00 \\
\hline 7422 & $V E G F A$ & $\begin{array}{l}\text { vascular endothelial growth } \\
\text { factor A }\end{array}$ & -2.06 & 0.05 & 1.99 \\
\hline 8030 & CCDC6 & $\begin{array}{l}\text { coiled-coil domain } \\
\text { containing } 6\end{array}$ & -7.46 & 0.65 & 1.62 \\
\hline 3915 & $L A M C 1$ & $\begin{array}{c}\text { laminin, gamma } 1 \text { (formerly } \\
\text { LAMB2) }\end{array}$ & -3.22 & 0.18 & 1.61 \\
\hline 54205 & CYCS & cytochrome c, somatic & -2.20 & 1.34 & 1.59 \\
\hline 1956 & $E G F R$ & $\begin{array}{l}\text { epidermal growth factor } \\
\text { receptor }\end{array}$ & -2.30 & -0.88 & 1.50 \\
\hline 613 & $B C R$ & breakpoint cluster region & -2.43 & -0.76 & 1.28 \\
\hline 208 & $A K T 2$ & $\begin{array}{l}\text { v-akt murine thymoma viral } \\
\text { oncogene homolog } 2\end{array}$ & 0.22 & -2.70 & 1.34 \\
\hline 10000 & AKT3 & $\begin{array}{l}\text { v-akt murine thymoma viral } \\
\text { oncogene homolog } 3\end{array}$ & -2.73 & -2.19 & 1.37 \\
\hline 5728 & PTEN & $\begin{array}{c}\text { phosphatase and tensin } \\
\text { homolog }\end{array}$ & 0.13 & -3.01 & 1.26 \\
\hline 861 & $R U N X 1$ & $\begin{array}{l}\text { runt-related transcription } \\
\text { factor } 1\end{array}$ & -3.21 & -3.90 & 1.26 \\
\hline 3914 & $L A M B 3$ & laminin, beta 3 & -2.31 & -0.20 & 1.04 \\
\hline
\end{tabular}

Table 3C: Downregulated genes by si-MTDH in "Endcytosis pathway"

\begin{tabular}{|c|c|c|c|c|c|}
\hline \multirow[t]{2}{*}{$\begin{array}{l}\text { Entrez } \\
\text { gene ID }\end{array}$} & \multirow[t]{2}{*}{ Gene symbol } & \multirow[t]{2}{*}{ Description } & \multicolumn{2}{|c|}{$\begin{array}{l}\text { si-MTDH transfectant } \\
\text { (fold-change) }\end{array}$} & \multirow[t]{2}{*}{$\begin{array}{c}\text { GSE19188 } \\
\text { (fold-change) }\end{array}$} \\
\hline & & & siRNA1 & SiRNA2 & \\
\hline 55040 & EPN3 & epsin 3 & 0.93 & -2.86 & 6.01 \\
\hline 57154 & SMURF1 & $\begin{array}{l}\text { SMAD specific E3 ubiquitin protein } \\
\text { ligase } 1\end{array}$ & -2.20 & -0.07 & 2.71 \\
\hline 83737 & ITCH & itchy E3 ubiquitin protein ligase & -2.20 & -0.67 & 2.42 \\
\hline 163 & $A P 2 B 1$ & $\begin{array}{c}\text { adaptor-related protein complex } 2, \\
\text { beta } 1 \text { subunit }\end{array}$ & -2.28 & -0.99 & 1.76 \\
\hline 9815 & GIT2 & $\begin{array}{l}\text { G protein-coupled receptor kinase } \\
\text { interacting ArfGAP } 2\end{array}$ & 0.06 & -2.30 & 1.53 \\
\hline 51100 & SH3GLB1 & $\begin{array}{l}\text { SH3-domain GRB2-like endophilin } \\
\text { B1 }\end{array}$ & -3.11 & -2.15 & 1.11 \\
\hline 9922 & IQSECI & IQ motif and Sec7 domain 1 & -0.14 & -2.90 & 1.35 \\
\hline 2869 & GRK5 & G protein-coupled receptor kinase 5 & -0.19 & -2.14 & 1.35 \\
\hline
\end{tabular}

that $m i R-145-5 p$ and its target gene TPD52 contributed to malignancy progression and in metastasis of brain tumor [31]. In colon cancer cells, overexpression of $m i R-145-5 p$ reduced STAT1 expression [32]. These facts suggest that list of candidate genes might be regulated by both $m i R-145-5 p$ and $m i R-145-3 p$ in lung cancer cells. These 
genes mediated cancer pathways that are important for understanding lung SCC pathogenesis. We focused on $M T D H$ in the present study and investigated its functional significance in lung SCC. MTDH is also termed astrocyte elevated gene-1 $(A E G-1)$ and lysine-rich CEACA-M1 coisolated (LYRIC). It was initially cloned from human fetal astrocytes following HIV-1 infection or tumor necrosis factor-alpha treatment [33]. The function of $M T D H$ is a downstream mediator of several signal pathways, such as PI3K/AKT, NFkB, MAPK and Wnt/ $\beta$-catenin $[34,35]$. These activated pathways are deeply involved in cancer cells proliferation, invasion, angiogenesis and metastasis $[34,35]$. Our function assays showed that knockdown of $M T D H$ inhibited cancer cell aggressiveness and affected downstream signal pathways under the following headings: "focal adhesion", "pathways in cancer", "endocytosis" and "cell cycle". Our findings in this study support the oncogenic function of $M T D H$ in lung SCC cells.

The primary finding of the present study is the overexpression of $M T D H$, a gene that is involved in the pathogenesis of lung SCC. Our large cohort study indicated that expression of $M T D H$ was upregulated in cancer tissues. Furthermore, Kaplan-Meier survival curves showed that high expression of $M T D H$ predicted poorer survival of lung SCC patients. Our functional study showed that silencing of MTDH inhibited lung-SCC cell migration and invasion. Metastasis is responsible for most of the mortality in lung cancer. Other studies demonstrated that high level $M T D H$ expression predicted poor survival of patients with esophageal squamous cell carcinoma and breast cancer [35-38].

Recent studies showed that several miRNAs control the expression of $M T D H$ in multiple types of cancer, such as $m i R-375, m i R-136, m i R-26 a$ and $m i R-145-5 p$ [39-44]. Downregulation of these miRNAs enhanced the expression of $M T D H$ in cancer cells. Several studies indicated that activation of $H$-Ras/PI3K signaling induce the expression of MYC, which binds to the $M T D H$ promoter region and enhances its expression [34, 45]. Interestingly, p53 appears to transcriptionally regulate $m i R-145-5 p$ by its interaction with a potential $\mathrm{p} 53$ response element in the pre-miR-145 promoter region and $m i R-145-5 p$ directly targets oncogenic MYC [46, 47]. In the human genome, $M T D H$ is located in $8 \mathrm{q} 22$. This area is associated with the center of activity for genomic amplification in multiple cancers [48]. Recent study showed that $M T D H$ and $M Y C$ cooperate to promote hepatic cancer [49]. Thus, it appears that overexpression of $M T D H$ in cancer cells enhances its aggressiveness.

In conclusion, downregulation of dual strand pre$m i R-145$ (miR-145-5p and miR-145-3p) was detected in lung SCC clinical specimens. Both miR-145-3p and $m i R-145-5 p$ act as antitumor miRNAs in lung SCC cells. Oncogenic $M T D H$ was directly regulated by these miRNAs. Expression of $M T D H$ is involved in lung SCC pathogenesis and its high expression predicts poorer survival of lung SCC patients. Elucidation of miR-1455p/miR-145-3p/MTDH-mediated molecular networks may lead to a better understanding of lung SCC pathogenesis and the development of new treatment protocols.

\section{MATERIALS AND METHODS}

\section{Clinical specimens, cell culture and RNA extraction}

From 2010 to 2013, Kagoshima University Hospital collected 33 lung SCCs and 22 noncancerous lung specimens from patients who underwent pneumonectomy. Our study was approved by the Institutional Review Board for Clinical Research of Kagoshima University School of Medicine. Each patient gave us prior written informed consent and approval.

We used the International Association for the Study of Lung Cancer TNM classification system to stage the samples. All samples were histologically graded [50].

Archival formalin-fixed paraffin embedded (FFPE) samples were used for qRT-PCR analysis. Eight FFPE tissue sections $(10-\mu \mathrm{m})$ were used for extraction of total RNA, using Recover All ${ }^{\mathrm{TM}}$ Total Nucleic Acid Isolation kits Ambion (Texas, USA) according to the manufacturer's protocols.

Two human lung SCC cell lines (SK-MES-1 and EBC-1) were obtained from Japanese Cancer Research Resources Bank (JCRB) and the American Type Culture Collection (Manassas, VA, USA), respectively.

\section{Quantitative real-time PCR (qRT-PCR)}

PCR quantification was carried out essentially as previously described [12-17]. TaqMan probes and primers for $M T D H$ (assay ID: Hs00757841_m1, Applied Biosystems, Foster City, CA, USA), EPN3 (HS00978957 m1), TPD52 (Hs00893105_m1), CYP27B1 (Hs01096154 m1), LMAN1 (Hs01557542), STAT1 (Hs01013996_m1) and TXNDC12 (Hs00210841_m1) were assay-on-demand gene expression products. To quantify the expression level of miRNAs, we utilized stem-loop RT-PCR for miR-145$5 p$ (assay ID: 002278, Applied Biosystems) and miR-145$3 p$ (assay ID: 002149, Applied Biosystems) following the manufacturer's protocol. mRNA and miRNA data were normalized to human GUSB (assay ID: Hs99999908_m1; Applied Biosystems) and RNU48 (assay ID: 001006; Applied Biosystems), respectively. The fold-change was calculated using the delta-delta $\mathrm{Ct}$ method.

\section{Transfection with mature miRNA and small interfering RNA (si-RNA) by transfection of lung SCC cells}

Here, we used the following miRNA species: Pre-miR ${ }^{\mathrm{TM}}$ miRNA precursors (hsa-miR-145-5p, assay 
ID: PM 11480; hsa-miR-145-3p, assay ID: PM 13036; negative control miRNA; assay ID: AM 17111) (Thermo Fisher). We also purchased the following from Invitrogen (Carlsbad, CA, USA): Stealth Select RNAi siRNA, siMTDH (assay ID: HSS 150644, and P/N: HSS 150646. Thermo Fisher Scientific (Waltham, MA USA) provided negative-control siRNA (D-001810-10). For transfection, RNAs were incubated with OPTI-MEM (Invitrogen) and Lipofectamine RNAiMax reagent (Invitrogen) as previously studies [12-17].

\section{Cell proliferation, migration, and invasion assays}

XTT assays were used to assess cell proliferation (Cell Proliferation Kit II, Roche Applied Sciences, Tokyo, Japan). Cell migration was analysed with wound healing assays. Modified Boyden chambers containing Transwellprecoated Matrigel membrane filter inserts were used to quantitate cellular invasion. Details of these assays were described as previously [12-17].

\section{Use of total genome expression and in silico analyses to identify genes regulated by $m i R-145-5 p$ and $m i R-145-3 p$ in lung SCC cells}

Specific genes affected by $m i R-145-5 p$ and $m i R$ 145-3p were identified by a combination of in silico and genome-wide gene expression analyses. Genes regulated by $m i R-145-5 p$ and $m i R-145-3 p$ were listed using the TargetScan database. We then attempted to identify targets using the EBC-1 cell line transfected with these miRNAs. A Sure Print G3 Human GE 8 X 60K Microarray (Agilent Technologies) was used for expression profiling of $m i R$ $145-5 p$ and $m i R-145-3 p$ transfectants. The microarray data were deposited into GEO (http://www.ncbi.nlm.nih.gov/ geo/), accession number GSE77790. Genes upregulated in NSCLC were obtained from publicly available data sets in GEO (accession numbers: GSE19188). The overall strategy is outlined in Figure 2.

\section{Regulation of targets downstream from $\mathrm{MTDH}$ in lung SCC}

We investigated lung SCC cells to identify pathways regulated by $M T D H$. We analyzed gene expression using si-MTDH-transfected EBC-1 cells. Microarray data were used for expression profiling of si-MTDH transfectants. The microarray data were deposited into GEO (accession number: GSE77790). We analyzed common down- or upregulated genes using the GEO dataset.

\section{Western blotting}

Protein lysates $(50 \mu \mathrm{g})$ were obtained $96 \mathrm{~h}$ after transfection. Proteins were separated by NuPAGE on 4-12\% bis-tris gels (Invitrogen) and transferred to polyvinylidene fluoride membranes. Membranes were immunoblotted with diluted polyclonal MDTH antibody (1:200; HPA 015104; Sigma-Aldrich, St Lois, MO, USA) and GAPDH antibody (1:100; MAB374; Chemicon, Temecula, CA, USA). The procedure of Western blotting was described previously [12-17].

\section{Plasmid construction and dual-luciferase reporter assay}

The partial wild-type sequence of the $M T D H$ 3 '-untranslated region (UTR) was inserted between the XhoI-PmeI restriction sites in the 3'-UTR of the hRluc gene in the psiCHECK-2 vector (C8021; Promega, Madison, WI, USA). Alternatively, we used sequences that were missing the miR-145-5p target sites (position 31513157 or position $3503-3510$ ) or the $m i R-145-3 p$ target site (position 147-153). The synthesized DNA was cloned into the psiCHECK-2 vector. EBC-1 cells were transfected with $20 \mathrm{ng}$ of the vector, $20 \mathrm{nM}$ microRNAs, and $1 \mu \mathrm{L}$ Lipofectamine 2000 (Invitrogen) in $100 \mu \mathrm{L}$ Opti-MEM (Invitrogen). The procedure of dual-luciferase reporter assay was described previously [12-17].

\section{TCGA database analysis of lung SCC specimens}

The clinical significance of $M T D H$ in lung SCC was assessed by RNA sequencing and a putative CNV database (predicted by a GISTIC algorithm) in LUSCC TCGA (The Cancer Genome Atlas: https://tcga-data.nci. nih.gov/). The genomic and clinical data were retrieved from cBioportal (http:/www.cbioportal.org/) or UCSC Cancer Browser (https://genome-cancer.ucsc.edu/proj/ site/hgHeatmap/). The normalized mRNA expression values in the RNA sequencing data were processed and distributed in $\log _{2}$ transformed RSEM (RNA-Seq by Expectation Maximization) values (cBioportal) or $\log _{2}$ transformed (RSEM+1) (UCSC Cancer Browser). The Z-scores of $M T D H$ mRNA expression data and clinical sample information corresponding to LUSCC patients were collected from cBioportal. The $M T D H$ altered group $(\mathrm{CNV}=$ amplification or gain, or mRNA Z-score $>1.5$, total 313 cases) and the $M T D H$ non-altered group (CNV $=$ diploid or heterozygous loss, and mRNA Z-score $\leq 1.5$, total 184 cases) were analyzed by Kaplan-Meier survival curves and log-rank statistics.

\section{Statistical analysis}

The relationships between 2 groups and the numerical values obtained by RT-qPCR were analysed using Mann-Whitney U-tests. Spearman's rank test was used to evaluate the correlations between the expression of $m i R-145-5 p$ and $m i R-145-3 p$. The relationships among more than 3 variables and numerical values were analysed using the Bonferroni-adjusted Mann-Whitney U-test. Survival analysis was analysed by the KaplanMeier method and log-rank test, using Stat Mate software 
(version 4.01, ATMS Co., Tokyo, Japan). All other analyses were performed using Expert StatView (version 5, SAS Institute Inc., Cary, NC, USA).

\section{ACKNOWLEDGMENTS}

This study was supported by the KAKENHI, grant numbers (C) 15K10801 and (C) 16K19458.

\section{CONFLICTS OF INTEREST}

The authors declare no conflicts of interest.

\section{REFERENCES}

1. Torre LA, Bray F, Siegel RL, Ferlay J, Lortet-Tieulent J and Jemal A. Global cancer statistics, 2012. CA: a cancer journal for clinicians. 2015; 65:87-108.

2. Travis WD. Pathology of lung cancer. Clinics in chest medicine. 2011; 32:669-692.

3. Reck M, Heigener DF, Mok T, Soria JC and Rabe KF. Management of non-small-cell lung cancer: recent developments. Lancet (London, England). 2013; 382:709-719.

4. Bartel DP. MicroRNAs: genomics, biogenesis, mechanism, and function. Cell. 2004; 116:281-297.

5. FilipowiczW, Bhattacharyya SN and Sonenberg N. Mechanisms of post-transcriptional regulation by microRNAs: are the answers in sight? Nature reviews Genetics. 2008; 9:102-114.

6. Singh SK, Pal Bhadra M, Girschick HJ and Bhadra U. MicroRNAs--micro in size but macro in function. The FEBS journal. 2008; 275:4929-4944.

7. Iorio MV and Croce CM. MicroRNAs in cancer: small molecules with a huge impact. J Clin Oncol. 2009; 27:5848-5856.

8. Esquela-Kerscher A and Slack FJ. Oncomirs - microRNAs with a role in cancer. Nature reviews Cancer. 2006; 6:259-269.

9. Wiemer EA. The role of microRNAs in cancer: no small matter. Eur J Cancer. 2007; 43:1529-1544.

10. Kikkawa N, Hanazawa T, Fujimura L, Nohata N, Suzuki H, Chazono H, Sakurai D, Horiguchi S, Okamoto Y and Seki N. miR-489 is a tumour-suppressive miRNA target PTPN11 in hypopharyngeal squamous cell carcinoma (HSCC). Br J Cancer. 2010; 103:877-884.

11. Itesako T, Seki N, Yoshino H, Chiyomaru T, Yamasaki T, Hidaka H, Yonezawa T, Nohata N, Kinoshita T, Nakagawa M, Enokida $\mathrm{H}$. The microRNA expression signature of bladder cancer by deep sequencing: the functional significance of the miR-195/497 cluster. PLoS One. 2014; 9:e84211.

12. Fukumoto I, Kinoshita T, Hanazawa T, Kikkawa N, Chiyomaru T, Enokida H, Yamamoto N, Goto Y, Nishikawa R, Nakagawa M, Okamoto Y and Seki N. Identification of tumour suppressive microRNA-451a in hypopharyngeal squamous cell carcinoma based on microRNA expression signature. Br J Cancer. 2014; 111:386-394.
13. Fukumoto I, Hanazawa T, Kinoshita T, Kikkawa N, Koshizuka K, Goto Y, Nishikawa R, Chiyomaru T, Enokida H, Nakagawa M, Okamoto Y and Seki N. MicroRNA expression signature of oral squamous cell carcinoma: functional role of microRNA-26a/b in the modulation of novel cancer pathways. Br J Cancer. 2015; 112:891-900.

14. Goto Y, Kojima S, Nishikawa R, Kurozumi A, Kato M, Enokida H, Matsushita R, Yamazaki K, Ishida Y, Nakagawa M, Naya Y, Ichikawa T and Seki N. MicroRNA expression signature of castration-resistant prostate cancer: the microRNA-221/222 cluster functions as a tumour suppressor and disease progression marker. $\mathrm{Br} \mathrm{J}$ Cancer. 2015; 113:1055-1065.

15. Mataki H, Enokida H, Chiyomaru T, Mizuno K, Matsushita R, Goto Y, Nishikawa R, Higashimoto I, Samukawa $\mathrm{T}$, Nakagawa M, Inoue $\mathrm{H}$ and Seki N. Downregulation of the microRNA-1/133a cluster enhances cancer cell migration and invasion in lung-squamous cell carcinoma via regulation of Coronin1C. J Hum Genet. 2015; 60:53-61.

16. Mataki H, Seki N, Chiyomaru T, Enokida H, Goto Y, Kumamoto T, Machida K, Mizuno K, Nakagawa M and Inoue H. Tumor-suppressive microRNA-206 as a dual inhibitor of MET and EGFR oncogenic signaling in lung squamous cell carcinoma. Int J Oncol. 2015; 46:1039-1050.

17. Mizuno K, Seki N, Mataki H, Matsushita R, Kamikawaji K, Kumamoto T, Takagi K, Goto Y, Nishikawa R, Kato M, Enokida $\mathrm{H}$, Nakagawa $\mathrm{M}$ and Inoue $\mathrm{H}$. Tumor-suppressive microRNA-29 family inhibits cancer cell migration and invasion directly targeting LOXL2 in lung squamous cell carcinoma. Int J Oncol. 2016; 48:450-460.

18. Matsushita R, Yoshino H, Enokida H, Goto Y, Miyamoto K, Yonemori M, Inoguchi S, Nakagawa M, Seki N. Regulation of UHRF1 by dual-strand tumor-suppressor microRNA-145 (miR-145-5p and miR-145-3p): inhibition of bladder cancer aggressiveness. Oncotarget. 2016; 7:28460-87. doi: 10.18632/oncotarget.8668.

19. Matranga C, Tomari Y, Shin C, Bartel DP and Zamore PD. Passenger-strand cleavage facilitates assembly of siRNA into Ago2-containing RNAi enzyme complexes. Cell. 2005; 123:607-620.

20. Matsushita R, Seki N, Chiyomaru T, Inoguchi S, Ishihara T, Goto Y, Nishikawa R, Mataki H, Tatarano S, Itesako T, Nakagawa $\mathrm{M}$ and Enokida H. Tumour-suppressive microRNA144-5p directly targets $\mathrm{CCNE} 1 / 2$ as potential prognostic markers in bladder cancer. Br J Cancer. 2015; 113:282-289.

21. Kano M, Seki N, Kikkawa N, Fujimura L, Hoshino I, Akutsu Y, Chiyomaru T, Enokida H, Nakagawa M and Matsubara H. miR-145, miR-133a and miR-133b: Tumorsuppressive miRNAs target FSCN1 in esophageal squamous cell carcinoma. Int J Cancer. 2010; 127:2804-2814.

22. Chiyomaru T, Enokida H, Tatarano S, Kawahara K, Uchida Y, Nishiyama K, Fujimura L, Kikkawa N, Seki N, Nakagawa M. miR-145 and miR-133a function as tumor suppressors and directly regulate FSCN1 expression in bladder cancer. Br J Cancer. 2010; 102:883-891. 
23. Yoshino H, Enokida H, Itesako T, Kojima S, Kinoshita T, Tatarano S, Chiyomaru T, Nakagawa M, Seki N. Tumorsuppressive microRNA-143/145 cluster targets hexokinase-2 in renal cell carcinoma. Cancer Sci. 2013; 104:1567-1574.

24. Kojima S, Enokida H, Yoshino H, Itesako T, Chiyomaru T, Kinoshita T, Fuse M, Nishikawa R, Goto Y, Naya Y, Nakagawa M, Seki N. The tumor-suppressive microRNA-143/145 cluster inhibites cell migration and invasion by targeting GOLM1 in prostate cancer. J Hum Genet. 2014; 59:78-87.

25. Sachdeva M, Mo YY. miR-145-mediated suppression of cell growth, invasion and metastasis. Am J Transl Res. 2010; 2:170-180.

26. Kent OA, McCall MN, Cornish TC, Halushka MK. Lessons from miR-143/145: the importance of cell-type localization of miRNAs. Nucleic Acids Res. 2014; 42:7528-7538.

27. Gregory RI, Chendrimada TP, Cooch N and Shiekhattar R. Human RISC couples microRNA biogenesis and posttranscriptional gene silencing. Cell. 2005; 123:631-640.

28. Ahmed F, Ansari HR and Raghava GP. Prediction of guide strand of microRNAs from its sequence and secondary structure. BMC bioinformatics. 2009; 10:105.

29. Goto Y, Nishikawa R, Kojima S, Chiyomaru T, Enokida H, Inoguchi S, Kinoshita T, Fuse M, Sakamoto S, Nakagawa M, Naya Y, Ichikawa T, Seki N. Tumor-suppressive microRNA-224 inhibits cancer cell migration and invasion via targeting oncogenic TPD52 in prostate cancer. FEBS Lett. 2014; 588:1973-1982.

30. Byrne JA, Frost S, Chen Y, Bright RK. Tumor protein D52 (TPD52) and cancer-oncogene understudy or understudied oncogene? Tumour Biol. 2014; 35:7369-7382.

31. Donzelli S, Mori F, Bellissimo T, Sacconi A, Casini B, Frixa T, Roscilli G, Aurisicchio L, Facciolo F, Pompili A, Carosi MA, Pescarmona E, Segatto O, Pond G, Muti P, Telera S, Strano S, Yarden Y, Blandino G. Epigenetic silencing of miR-145-5p contributes to brain metastasis. Oncotarget. 2015; 6:35183-35201. doi: 10.18632/oncotarget.5930.

32. Gregersen LH, Jacobsen AB, Frankel LB, Wen J, Krogh A, Lund AH. MicroRNA-145 targets YES and STAT1 in colon cancer cells. PLoS One. 2010; 5:e8836.

33. Noch EK and Khalili K. The role of AEG-1/MTDH/LYRIC in the pathogenesis of central nervous system disease. Advances in cancer research. 2013; 120:159-192.

34. Hu G, Wei Y and Kang Y. The multifaceted role of MTDH/ AEG-1 in cancer progression. Clin Cancer Res. 2009; 15:5615-5620.

35. Huang Y and Li LP. Progress of cancer research on astrocyte elevated gene-1/Metadherin. Oncol Lett. 2014; 8:493-501.

36. Brown DM and Ruoslahti E. Metadherin, a cell surface protein in breast tumors that mediates lung metastasis. Cancer cell. 2004; 5:365-374.

37. Liang Y, Hu J, Li J, Liu Y, Yu J, Zhuang X, Mu L, Kong $\mathrm{X}$, Hong D, Yang Q and Hu G. Epigenetic Activation of TWIST1 by MTDH Promotes Cancer Stem-like Cell Traits in Breast Cancer. Cancer Res. 2015; 75:3672-3680.
38. Yu C, Chen K, Zheng H, Guo X, Jia W, Li M, Zeng M, Li J and Song L. Overexpression of astrocyte elevated gene-1 (AEG-1) is associated with esophageal squamous cell carcinoma (ESCC) progression and pathogenesis. Carcinogenesis. 2009; 30:894-901.

39. Nohata N, Hanazawa T, Kikkawa N, Mutallip M, Sakurai D, Fujimura L, Kawakami K, Chiyomaru T, Yoshino H, Enokida H, Nakagawa M, Okamoto Y and Seki N. Tumor suppressive microRNA-375 regulates oncogene AEG-1/MTDH in head and neck squamous cell carcinoma (HNSCC). J Hum Genet. 2011; 56:595-601.

40. Hui AB, Bruce JP, Alajez NM, Shi W, Yue S, Perez-Ordonez B, Xu W, O'Sullivan B, Waldron J, Cummings B, Gullane P, Siu L, Liu FF. Significance of dysregulated metadherin and microRNA-375 in head and neck cancer. Clin Cancer Res. 2011; 17:7539-7550.

41. He XX, Chang Y, Meng FY, Wang MY, Xie QH, Tang F, Li PY, Song YH, Lin JS. MicroRNA-375 targets AEG-1 in hepatocellular carcinoma and suppresses liver cancer cell growth in vitro and in vivo. Oncogene. 2012; 31:3357-3369.

42. Zhao J, Wang W, Huang Y, Wu J, Chen M, Cui P, Zhang W and Zhang Y. HBx elevates oncoprotein AEG-1 expression to promote cell migration by downregulating miR-375 and miR-136 in malignant hepatocytes. DNA and cell biology. 2014; 33:715-722.

43. Zhang B, Liu XX, He JR, Zhou CX, Guo M, He M, Li MF, Chen GQ and Zhao Q. Pathologically decreased miR26a antagonizes apoptosis and facilitates carcinogenesis by targeting $\mathrm{MTDH}$ and EZH2 in breast cancer. Carcinogenesis. 2011; 32:2-9.

44. Dong R, Liu X, Zhang Q, Jiang Z, Li Y, Wei Y, Li Y, Yang Q, Liu J, Wei JJ, Shao C, Liu Z and Kong B. miR-145 inhibits tumor growth and metastasis by targeting metadherin in high-grade serous ovarian carcinoma. Oncotarget. 2014; 5:10816-10829. doi: 10.18632/oncotarget.2522.

45. Lee SG, Su ZZ, Emdad L, Sarkar D, Franke TF and Fisher PB. Astrocyte elevated gene-1 activates cell survival pathways through PI3K-Akt signaling. Oncogene. 2008; 27:1114-1121.

46. Sachdeva M, Zhu S, Wu F, Wu H, Walia V, Kumar S, Elble $\mathrm{R}$, Watabe K and Mo YY. p53 represses c-Myc through induction of the tumor suppressor miR-145. Proc Natl Acad Sci U S A. 2009; 106:3207-3212.

47. Suzuki HI, Yamagata K, Sugimoto K, Iwamoto T, Kato S and Miyazono K. Modulation of microRNA processing by p53. Nature. 2009; 460:529-533.

48. Anttila V, Stefansson H, Kallela M, Todt U, Terwindt GM, Calafato MS, Nyholt DR, Dimas AS, Freilinger T, MullerMyhsok B, Artto V, Inouye M, Alakurtti K, et al. Genomewide association study of migraine implicates a common susceptibility variant on 8q22.1. Nature genetics. 2010; 42:869-873.

49. Srivastava J, Siddiq A, Gredler R, Shen XN, Rajasekaran D, Robertson CL, Subler MA, Windle JJ, Dumur CI, Mukhopadhyay ND, Garcia D, Lai Z, Chen Y, Balaji U, 
Fisher PB and Sarkar D. Astrocyte elevated gene-1 and c-Myc cooperate to promote hepatocarcinogenesis in mice. Hepatology. 2015; 61:915-929.

50. Shepherd FA, Crowley J, Van Houtte P, Postmus PE, Carney D, Chansky K, Shaikh Z and Goldstraw P. The
International Association for the Study of Lung Cancer lung cancer staging project: proposals regarding the clinical staging of small cell lung cancer in the forthcoming (seventh) edition of the tumor, node, metastasis classification for lung cancer. Journal of thoracic oncology. 2007; 2:1067-1077. 